\title{
WILLIAM OGLE OF DERBY AND FLORENGE NIGHTINGALE
}

\author{
by \\ DOUGLAS HUBBLE
}

THE facts concerning the life of William Ogle are briefly set out in Munk's Roll of the Fellows of the Royal College of Physicians of London (Iv, I64) as follows:

Ogle, William, b. Jan. 1824; d. 16 May 1905. M.A., M.D. Cantab., F.R.C.P. (1868), J.P. William Ogle was born at Skirbeck Vicarage, near Boston in Lincolnshire, his father being vicar of the parish. He was at school at Rugby under Dr. Arnold and an undergraduate at St. Catherine's College, Cambridge, where he was afterwards elected to a fellowship. He studied medicineat Edinburgh, the Rotunda Hospital, Dublin, and St. George's Hospital, London, taking the Cambridge Licence in 1853 . After a few years in London, during which he was associated with the Pimlico Provident Dispensary, he moved in 1860 to Derby where he lived for the remainder of his long life. Here he became physician and later consulting physician to the Derbyshire Royal Infirmary and founded the Nursing and Sanitary Institution. Ogle was a deeply religious man and a supporter of the Young Men's Christian Association. He married Margaret Lambert of Bradford in 1860 and had two sons.

William Ogle was an ardent reformer; his devotion to his chosen causes was inspired both by professional enthusiasm and by evangelical zeal. The poor must have good medical care; the profession must improve both its standards and its status; Derby must take an adequate part, by enlarging its Infirmary and by establishing a training-school for nurses, in the campaign for medical reform inspired by Miss Nightingale-and in all these affairs God must be served.

To bring his plans for the Infirmary to success he sought the support of Miss Nightingale, and the seven letters* which he received from her (now, by the kindness of the Ogle family, deposited in the Library of the Royal College of Physicians) illustrate well both her mental strength (despite her bodily weakness) and her powers of expression. William Ogle's letters to her are preserved in the Nightingale Manuscripts ( $4775^{8} \mathrm{vol}$. CLVI) in the British Museum. $\dagger$ The first of his letters is undated and the next seven were written between 28 December 1864 and 6 November 1865 . The remaining nine letters were written twentyfour years later when he was again seeking Miss Nightingale's support in regard to the plans for rebuilding the Infirmary and particularly for his proposals for an alteration of rules regarding the qualifications of house-visitors and medical officers.

Her first letter is dated the 2 January 1865 , and the seventh the 18 May 1866 . The first letter is sent from 27 Norfolk Street, the next five from 34 South Street

* See the Appendix, page 207.

† I am indebted to Sir Zachary Cope for telling me of these letters. 
and the last from her permanent home, 35 South Street, to which she moved in October 1865 . The first letter, typical of hundreds written by Miss Nightingale, is a conventional reply to the seeker of information and the suppliant for support.

In the second, an issue between them is firmly joined: she promptly refuses to be led into religious debate. Her letter opens:

I do not, of course, enter into the ecclesiastical question. I have helped rampant Roman Catholics, rampant Puseyites, rampant Nonconformists of all kinds, rampant Evangelicalsall, as far as I was able- to obtain good nurses.

In her third letter, she resists his further attempt to involve her personally on his side:

I wish to inform all sides . . . and to take part with none . . . I should not be a 'Patroness' (a word I detest) of any.

Eleven days later he receives a further rebuff; she refuses to go into action on his side:

opposition arises from jealousy of the separate action of one member. This is my almost quotidian experience and I have determined for the sake of the cause, much more than for my own (for I am used to being skinned alive every day like the eels) to avoid this for the future.

In the fifth letter which is not complete, she again states her reasons for refusing to engage in political and religious struggles. Four months elapse, the building committee in Derby has been formed, architects' plans are under discussion, and in the course of a week, Dr. Ogle writes her two letters. Her next letter explains that, although she has not replied to his letters on the same day that she wrote to Mr. Wright, the chairman of the Building Committee who is now officially seeking her opinion, yet she would not have Dr. Ogle think she has neglected his three letters. She discusses the architects' plans with him and promises to do so in greater detail later, yet she will not give him an opinion as to whether the Infirmary should be completely rebuilt or not: 'The question has not been asked me. And you see, like a ghost, I can only speak when spoken to.'

The last letter, written six months later, acknowledges the receipt of Dr. Ogle's privately printed 'Letter to the Governors of the Derbyshire Infirmary'. Dr. Ogle published this 'Letter' to acquaint the members of the Quarterly Meeting with the need for rebuilding the Infirmary which had been instanced in the Hospital Blue Book, published in 1864 as a report of the Medical Officer of the Privy Council, as a hospital whose structure was defective and obsolete. $\mathrm{He}$ describes the inadequacies of the nursing staff-insufficient and those few untrained-and states that Miss Nightingale is willing, from her intense interest' and 'since it is the Infirmary of her own county', to act quickly in the provision of a trained matron and trained nurses from the Nightingale School 


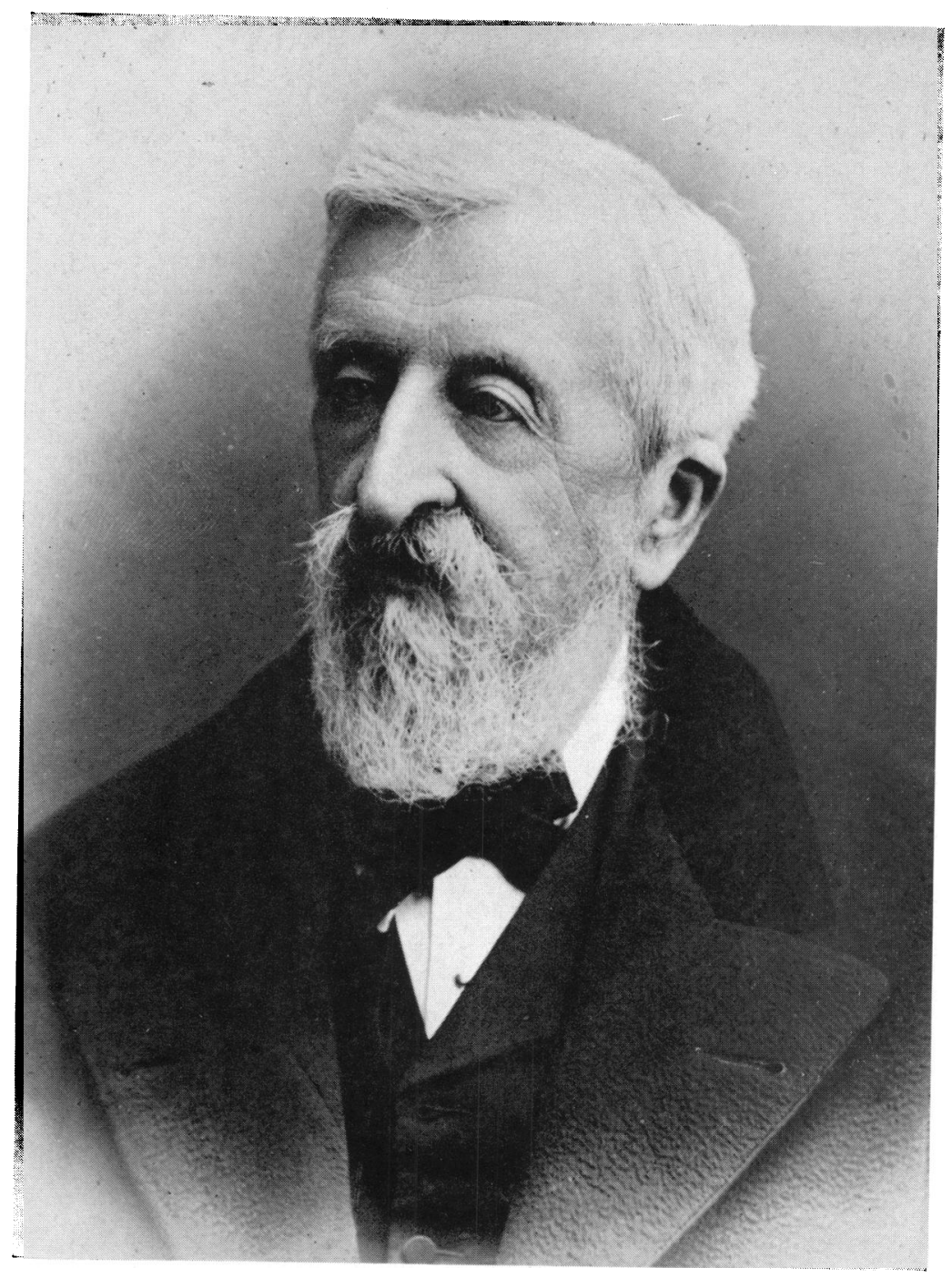

Fig. I

WILLIAM OGLE, M.D., F.R.C.P.

(1824-1905) 


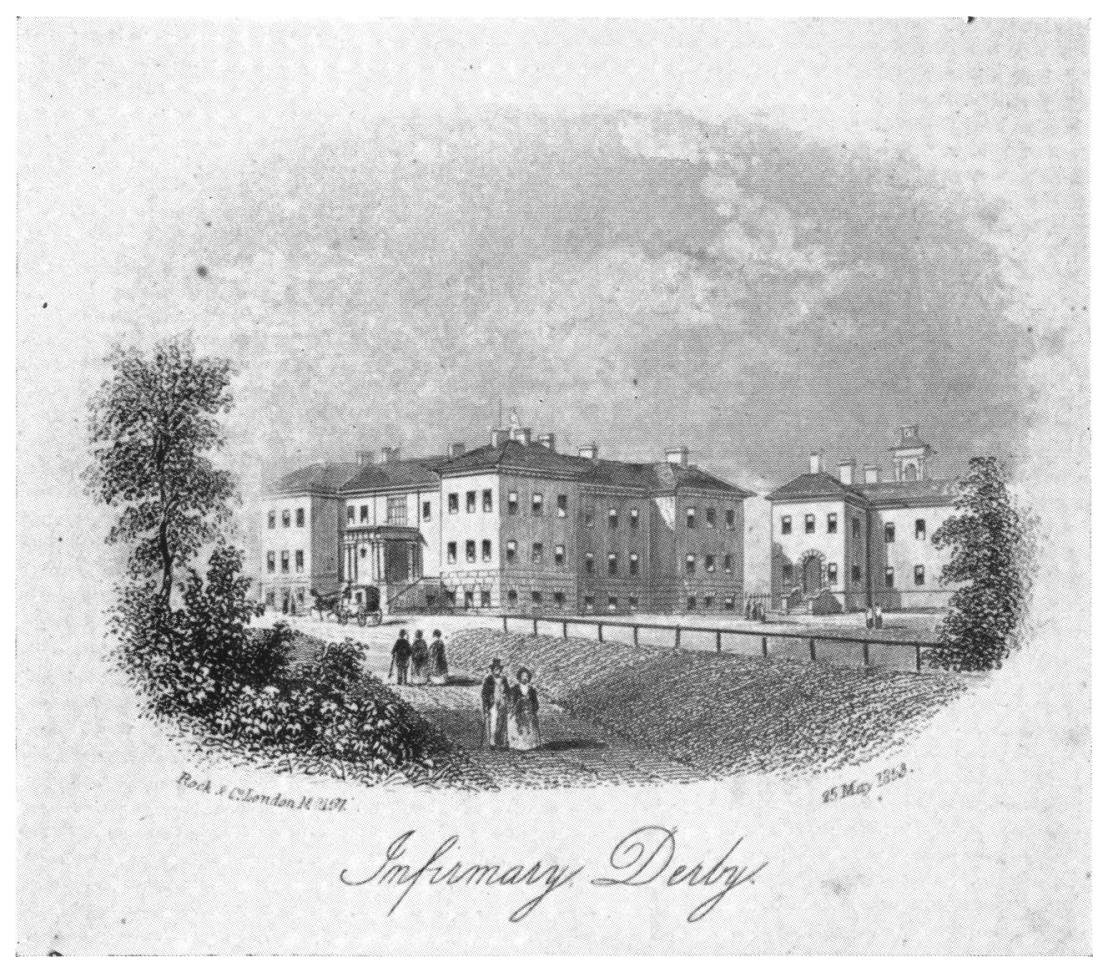

Fig. 2

The Derbyshire Royal Infirmary as it was in 1853 before the extensions suggested by Miss Nightingale were made. 


\section{William Ogle of Derby and Florence Nightingale}

at St. Thomas'. There is nothing in the tract of religion; Dr. Ogle is discreetly quiet concerning his evangelical enthusiasms. Miss Nightingale's last letter shows that he was not so discreet in his last letter to her. She has failed to rebuff him with reason and argument, and now she obliquely adds the weapon of ridicule.

I believe that we shall be able to furnish you with a Lady Supt. (certainly the lady we propose will not lend herself to the charge of being the 'ecclesiastical' head of a 'Sisterhood'). Mrs. Wardroper, our Matron of St. Thomas' and I had a good laugh over that paragraph of your letter, tho' I did not tell her it was yours.

Dr. Ogle had failed, as all other men failed, to persuade the implacable Miss Nightingale to change her opinions. But when she wrote,

I rejoice in the great and unexampled progress you have made in public opinion at Derby in the cause of Hospital reform-very much owing to yourself

-her words were sincere enough, for William Ogle's influence had without doubt greatly advanced the cause of hospital reform in Derby. The Nightingale School for Nurses had opened with Mrs. Wardroper as Superintendent on 24 June I86o and by the I November I866, Miss Elizabeth Frances Maria Kilvert, the nominee of Mrs. Wardroper, and trained at the Nightingale School, was appointed the first Lady Superintendent of the Derbyshire Infirmary and with her she brought four trained nurses. At the same Quarterly Meeting at which these appointments were made, a building committee under the chairmanship of Mr. F. Wright was instructed to prepare plans for the erection of a new wing and the alteration of the existing building according to the recommendations of Miss Nightingale. Mr. Wright had indeed taken over from Dr. Ogle the correspondence with Miss Nightingale and in the British Museum are eighteen of his letters written between 9 October 1865 and 18 July $1867 . *$ On 17 December I872, the new Nightingale Wing was opened by the Prince and Princess of Wales.

In all these affairs it appears from the minutes of the Board of Management of the Infirmary that Dr. Ogle had to be content with creating an opinion favourable to reform and the more powerful members of the Board had to be convinced before action was taken. He had been on the staff of the Infirmary only for four years when he began the correspondence with Miss Nightingale. The circumstances of his election are thus recorded in the minutes of the Board of Management:

At a special general meeting on 27th August 1860, the Hon. Rev. Frederick Curzon being in the chair, Dr. William Ogle was elected Physician to the Infirmary. He was proposed by Mr. Francis Wright and seconded by W. P. Thornhill Esq., M.P. He was given 226 votes while his rival Dr. Brigstocke was awarded 48 votes. A house-surgeon was elected by the same meeting, and notwithstanding the precautions taken to prevent mistakes there were found in Dr. Ogle's box 14 house-surgeons' tickets.

* Sir Zachary Cope kindly drew my attention to these letters. 


\section{Douglas Hubble}

Dr. Ogle's influence was not the consequence of seniority but was due to his loyalty, knowledge and enthusiasm. In his fourth letter to Miss Nightingale on 30 May 1865 , he wrote:

I came to Derby as a stranger four and a half years ago invited, I may almost say, by the Derbyshire Infirmary. I look therefore upon the Derbyshire Infirmary as having a great claim upon me; and anything that I can do to improve it I hold to be a first duty. I know it will be uphill work but at the same time I have had very much to encourage me.

Despite the strong and continued support of Mr. Francis Wright his plans were not always brought to a successful conclusion. In April I 867 Dr. Ogle wrote to the Board suggesting that probationer nurses should be accepted for training at the Infirmary. His advice was rejected at first and it was not until seven years later that his proposal was adopted. His suggested reforms were not always practicable. For example, in 1884 he addressed a privately printed pamphlet to the Governors proposing that the rules defining the eligibility of physicians applying for election should exclude those "who practised, or were in partnership with any gentleman who practised, pharmacy'. Physicians in those days charged a guinea a visit for patients in their family practice, and consulting work was limited. It is probable that in 1884 Dr. Ogle was the only physician in Derby who did not add to his income by dispensing medicines. The economic difficulties of a young family doctor, Lydgate, who refused to sell drugs (a portrait said to be drawn from life and to represent the early struggles of Clifford Allbutt) are described in George Eliot's novel Middlemarch, published in $187 \mathrm{I}-2$. Ogle's proposal was overwhelmingly rejected and at the subsequent election two dispensing physicians, Dr. W. Benthall and Dr. G. A. Greaves, were appointed.

He was still continuing the struggle in 1889 when he wrote to Miss Nightingale,

My greatest difficulty is as to the qualification of Hon. Medical Officers-as the rule stands at present a nobody would have the best chance. A stranger, however high his qualifications, would be nowhere-as one of my colleagues said the other day, 'We don't want any London men'. The old rule under which I was elected 29 years ago did not allow the physician to practise 'surgery, midwifery or pharmacy'. I have yielded all but the last-on that I take my stand. It has cost me hundreds of pounds a year but to have had any hand in the transition from 'darkness to light' is worthy every penny.

At his own retirement in 1891 , Ogle circulated another 'Address to the Governors' (now of the Derbyshire Royal Infirmary) - he had a weakness for circulating his privately printed tracts-giving the same advice. Once again his proposal was rejected, and once more he was in a minority of one. Ogle was right in principle, but the Governors were also right to recognize his proposal as impracticable at that time; in fact, 30 years were to pass before another non-dispensing physician was appointed; and that same physician (Hugh Barber) became in 1933 the second F.R.C.P. to practise in Derby, sixty-five years after Ogle's election to the Fellowship. 


\section{William Ogle of Derby and Florence Nightingale}

His other proposals for medical reform were published in various addresses and letters between 1865 and 1878 . He argued that medicine should be brought in its full efficiency to every man's door; that this required a scheme for annual fixed payments to family doctors; that family doctors should work in a group to provide joint surgeries and to share their visits so that no doctor was overworked. By such a scheme the poor would be well cared for in illness, disease could be early recognized and its further progress prevented. He preached, for there was an evangelical fervour in his writing borrowed from the Victorian pulpit - preventive medicine, group medical practice, and a health service for all, rich and poor, young and old. His proposals were defeated by individualism both in the profession and in the public, and by the tardy emergence of the social conscience. What Ogle urged doctors to do for themselves and their patients was 80 years later provided by the State. He had knowledge, vision, courage and tenacity, and the acceptance of his ideas would have changed the face of medical practice in this country. But these qualities in reformers are not enough for success, as he himself must have learnt in the small affairs of the Derby Infirmary. If reformers are not themselves powerful, they must gain the support of those in high places. There is no evidence that Ogle's ideas made any impact on his generation, and when in our time they came to be fiercely debated the name of William Ogle was not remembered.

There were perhaps other reasons for this. He was doctrinaire. His portrait -notwithstanding his sympathetic eyes-shows a man somewhat formidable and humourless, a man pedantic and tactless despite his integrity. On 6 November 1865 , he wrote in a letter to Miss Nightingale that 'the entrance (of the Infirmary) faces north and a little to the east'. Later on the same day he wrote again:

My dear Madam,

I find the aspect of the Infirmary is nearly due east and not north.

I am, dear Madam,

Yours faithfully, WILLIAM OGLE.

In another letter to her in 1889 , he gave the following opinion of house-visitors,

on the other hand if they were, as they have been in my time, unmitigated busybodies without either knowledge or sympathy, the less power they have the better.

His clinical writings confirm the impression of pedantry. His paper on 'A simple mode of tabulating symptons in clinical records' published in the St. George's Hospital Reports in 1872, describes a method far from simple, ingenious but impracticable, painstaking but unrewarding. His article on the application of this method to a case of diphtheria written in 1860 for Dr. Beale's Archives of Medicine, is the work of a careful clinician, but it cannot have been read with enthusiasm by a generation aware of the writings of the great medical observers. His best paper was published in the St. George's Hospital Reports (1879. IX. 701) on 'Observations in Outbreaks of Diphtheria in Rural Districts'. 


\section{Douglas Hubble}

It has brought him a curious, though anonymous, immortality. He appears to have been the first writer to have used the word 'immunity' in a medical sense, for the Oxford New English Dictionary quotes as its first illustration of the meaning of immunity the following sentence from his article, unfortunately without mentioning his name,

In one of the five instances ... the apparent immunity must have lasted at least two years, that being the interval between the diphtheritic visitations.*

He was himself the son of a parson and his two sons entered the Church. He was educated, as Munk's Roll relates, under Dr. Arnold at Rugby, and he never deviated from the tradition of evangelical churchmanship in which he was bred. His religion was the mainspring of his life, and it did not seem incongruous to him that it should inform all his actions, and permeate those everyday affairs which, to others less zealous than himself, were unrelated to the life of the spirit. We have already seen that Miss Nightingale could not restrain her ridicule at his notion that a training school for nurses should become an 'ecclesiastical Sisterhood'. It appeared to her, as it appears to us today, that Victorian evangelicalism too often accompanied, and possibly conditioned, an atrophy of the sense of humour. Dr. Ogle once described the case of a boy who inserted a stick into his rectum and he wrote:

The peculiarity of the case consisted partly in the moral obliquity of the youth, and partly in the fact of the stick having been introduced so high up into the bowel as to be quite across the abdomen. $t$

The story is still told in Derby today of his last illness in which he was attended by two doctors in partnership, a physician Dr. W. E. Benthall, and a surgeon Mr. John Kilvert. The patient prayed with them before they began their examination, ' $\mathrm{O}$ Lord, if it be Thy Will, bless the efforts of Thy two servants, Drs. Benthall and Kilvert,' and added in an aside, 'I always think it wise when addressing the Almighty to mention individuals by name.'

William Ogle died at the age of eighty-one, twenty-five years after his retirement from the active staff of the Derbyshire Royal Infirmary. He is remembered in Derby still with gratitude and respect for he was one of the founders of the Derby Medical Society in 1862 ; and the arms of the Ogle family are incorporated in its Presidential jewel. In his integrity and idealism he was a noble exemplar of Victorian medicine, and in his concept of the duty of medicine to the community he ranged far beyond the thought and practice of his generation.

I am grateful to Lady Hoskyns-Abrahall and the other members of the Ogle family for permission to deposit the Nightingale letters in the Library of the College of Physicians; and to the British Museum for permission to quote from the letters of Dr. Ogle.

* Dr. R. E. Smith kindly drew my attention to this quotation.

$\dagger$ Extract from the British Medical foumal, 12 December 1863, II, 647. Dr. Gerald Keatinge kindly supplied me with this reference and the anecdote which follows. 


\section{APPENDIX \\ SEVEN LETTERS WRITTEN BY MISS FLORENGE NIGHTINGALE TO DR. WILLIAM OGLE}

(1)

Sir,

$$
\begin{gathered}
\text { 27, Norfolk Street, } \\
\text { Park Lane, W. } \\
\text { 2/r/65. }
\end{gathered}
$$

I regret that, over-whelmed with business and illness as I am, I have not found time to answer your note before today.

I regret still more that, while the object is in its present immature state, it is impossible to enter into detailed recommendations. After you have people to join, a committee formed, and I suppose I must add money to work with, I shall be most happy to advise on any point you may wish.

When your society is formed, if you desire to send me the programme of your plans, I will do my best to consider them.

In the meantime, I will only say that I think experience shews that the Supt. of the nurses to be trained, and of the place where they are trained, should be one and the same person. The training school is of the first importance. The 'Home' of the second. The 'Home should be attached to the Hospital-not the Hospital to the "Home".' The Supt. must have herself the highest knowledge of nursing, be herself resident in the Hospital, make the training in nursing her first object, and be herself a trained nurse of the highest order.

I send a number of printed papers, in case they should be of any use to you, concerning our Training Schools at St. Thomas' and King's College Hospitals.

I also send the last Sanitary Reports and Prospectus of the 'Ladies Sanitary Association' in London. They would send you from their office a packet of tracts, report, etc., if you wish it, by which you would see what they are doing, and how far you could work in concert with them.

I beg that you will believe me, Sir,

Your faithful servant at any time that I can be of use.

FLORENCE NIGHTINGALE.

(2)

Private.

Sir,

In reply to your note of May 27 and its accompanying papers, I do not, of course, enter into the ecclesiastical question. I have helped rampant Roman Catholics, rampant Puseyites, rampant Nonconformists of all kinds, rampant Evangelicals-all, as far as I was able-to obtain good nurses. And all local organizations should be left to arrange themselves. You have seen them at Liverpool; an account of its Organization will shortly be printed and circulated. There they have had no difficulty with the ecclesiastical question (although the Rampants rage in Liverpool more than in any place I know). But on that common ground of nursing sick poor they have met together under the leading of one good man.

From their paper you will obtain the wisest hints as to a local organization.

The first thing you now want, in order to begin, is a good Training Matron for the Infirmary, and one who shall not only 'have entire charge of the housekeeping and the domestic service', but shall be a real trainer and 'superintendent' of nurses.

The next thing is to lay down the Regulations under which you should train. 


\section{Douglas Hubble}

I send you (confidentially) a paper prepared by me for the Government of India, at their request. (Please return it to me.) Should you find in it what you require, and should you put your scheme in form, I shall be very glad to go over it.

Do not make it too rigid. You will find that the system will have, to some extent, to form itself.

Your proposed changes in the Derbyshire General infirmary are part only of a reform which better nursing will entail upon you. The fact is-some general principles are required for guidance in all Hospitals.

If I live, I may perhaps try to do something of this kind-and it is impossible for me to answer in writing all the written questions addressed to me on this administrative matter. Some of the existing practices you describe, and also some of the changes you propose, in the Infirmary administration, are not altogether what I should adopt myself-I might even say that I should fancy the gravest mischief would result from some. But it would be unsafe to interfere unless the entire system, including the nursing, were reconstructed. 'New wine in old bottles' etc. (the proverb is somewhat musty).

I should be most glad and happy to go over carefully and criticize, for you, the plans of the proposed alterations in the building; I can form no judgment about them from description merely.

It would have afforded me great pleasure to have seen you-but I am so feeble that I doubt any good coming of my doing so in the present immature state of your plans. If however you think otherwise, I take so intense an interest in your scheme that I would see you, on Wednesday, the day you propose, at 3 p.m. or at 4 p.m. (if you will write me word) at this house.

Believe me, your ever faithful servant, FLORENCR NIGHTINGALE.

I should not be able to go over the building alterations with you viva voce. These, at all events, I must have time to go over by myself.

F. N:

(3)

Private.

June $2 / 65$.

34 South Street,

Park Lane,

London W.

Sir,

I have not hitherto answered your questions as to using my name, etc. because it appeared to me that I had sufficiently expressed what course I am compelled uniformly to take.

I can have no objection to its being stated that I will give the best information and opinion in my power as to any scheme you yourselves may propose: but, in doing so, I must clearly be considered as aiding merely because I am asked.

And the reason you will at once see is that I must not, even in appearance, interfere with the entire liberty of judgment and action on the part of your Committee and Association. I wish to inform all sides, to the best of my power, so as to give them the means of forming a judgment and to take part with none.

. Suffer me to say that I must also protect myself-or I should be continually dragged in to give my authority, such as it is worth, to schemes which all experience tells us cannot succeed.

I will give every assistance in my power, whether in the way of training nurses, or giving information, when asked. But it is necessary, in order to aid every side efficiently, that I should not become 'Patroness' (a word I detest) of any.

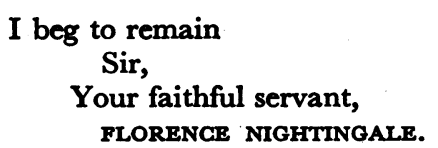




\section{William Ogle of Derby and Florence Nightingale}

(4)

Sir,

I am very sorry not to be able to assent to your citing me as an authority.

I am most willing to help your Committees to the utmost of my power-but to do this effectually, it is necessary that the Committees should ask my advice. This is not an opinion; or a fear of collision, on my part. It is the result of painful experience. My opinion is asked by and given to one member of a Committee great injury to the cause follows. I am involved in endless trouble. The Committee is convinced, at last, that I am right. The opposition arises from jealousy of the separate action of one member. This is my almost quotidian experience. And I have determined for the sake of the cause, much more than for my own (for I am used to being skinned alive every day like the eels) to avoid this for the future.

Your faithful servant, FLORENGE NIGHTINGALE.

(5)

Sir,

$$
\begin{gathered}
\text { 34, South Street, } \\
\text { Park Lane, } \\
\text { London, W. } \\
\text { 31/6/65. }
\end{gathered}
$$

In obedience to your express desire, but under protestation, I have criticized the enclosed sheet.

Such criticism generally only succeeds in alienating those who ask for it. And as the criticizers cannot possibly advance all the reasons for the criticism, it is besides useless labour in general.

To architect's plans this does not apply - and such criticism which I am almost weekly asked for I gladly give. Of course I apologize for the curtness of my marginal notes-such notes are like Telegrams-One cannot go down on one's knees in a Telegram.

Also, to avoid all possibility of mis-construction about the ecclesiastical question, it is not from indifferentism I say what I did. I have very strong opinions on religious subjects. But it was only by serving all sides, even Jews, that I could be of any use. I was asked to head a subscription for returning a man, with whose political opinions I have the strongest sympathies, to Parliament. But I declined. I have served the Army Sanitary administration with both political sides, when either was in power, and it was only thus I could do good.

Private.

$$
\begin{array}{r}
10 / \text { I } / 65 . \\
\text { 34, South Street, } \\
\text { Park Lane, } \\
\text { London, W. }
\end{array}
$$

My dear Sir,

I have to thank you for your three notes of Nov. 2, 6 etc.

In the first place, I will observe that I completely agree with you that, if the question were asked me whether to extend the old Hospital or to build a new one, I should certainly answerthe latter. But the question has not been asked me. And you see, like a ghost, I can only speak when I am spoken to.

The Fever Wing is a nest of holes and corners-equally destructive to health and to nursing. Nothing can be done with it but sweep it from end to end, in the way of improvement.

2. I have read your letters with the plans before me. The Architect, it is evident knows his business and the alterations and additions proposed are very good. I have made a good many 


\section{Douglas Hubble}

suggestions. But I have also said that to make the building what it should be, it should have two wings, (the proposed new one, and the Fever one re-built) and the old centre block should be used merely for administration etc.

Everything now depends on the course the Committee decide to take. If they adopt the latter course I have suggested and hope they will send me a pencil sketch, when I will go minutely into the details of accommodation for a Nursing Staff etc. etc. It is of no use my doing so till they have made up their minds.

I return you the enclosed, as you desire. And I should be much obliged to you to re-return it to me, when the Committee have decided. I will then go over in minute detail all these thingsAnd we can then decide whether it will be of any use to the cause your using my remarks on the Report. But at present it would perhaps be better to leave the whole matter in the hands of the Committee.

I have no doubt we shall have plenty of battle to fight afterwards.

I was very much obliged to you for sending me my notes and for your information.

It would be necessary, if I am further consulted, to tell me the average number of operations in the year-Men, Women of Surgical cases-Men, Women of Medical cases-Men, Women, etc. etc. etc. etc. It is impossible to arrange the Wards and the Nursing without knowing these and an infinity of other details. Oddly enough, sex was not given in the summary sent me of the proposed wards.

Your Pneumonia case undoubtedly was killed by want of nursing just as much as if he had been killed by an accident.

Such cases, neglected in such a way, are all but certain to prove fatal, unless the Head Nurse's eye is never off them and the Nurses.

If the Fever Wing had been built expressly to provide for the neglect of such cases, it could not have succeeded better.

I would most gladly have seen you, as you so kindly suggest. But I am completely disabled by illness from any such pleasure, however much I might desire it.

I write in haste, because I had not time to write to you on the same day I wrote to $\mathrm{Mr}$. Wright. And I would not have you think I have neglected your letters.

Pray believe me,

most faithfully yours, FLORENGE NIGHTINGALE.

(7)

Private.

May 18/66.

35 South Street,

Park Lane,

My dear Sir,

London. W.

It would be unpardonable of me not to have answered your kind letter of April 30- or acknowledged your 'Letter' to the Infirmary Governors before, if I had not to urge the everincreasing excuse of illness and business, and if I had not felt that I could do no good in the way you kindly proposed.

I have never entered into the controversial line, either in politics or in religion. I have given my services to any Government who would have them. I have also given my services to any Christian denomination (\& even to Jews and Mahometans) if they were authoritatively asked for. But, if they were asked for to support one 'party' against another, tho' I have been fool enough to sometimes do it, in the interest of the poor and the sick-never in the interest of 'party'-I have always had cause to repent of it - not from the vain trouble which rebounded upon me and which I did not so much mind as in the very interest of those poor and those sick which I was advocating.

I rejoice in the great and unexampled progress you have made in public opinion at Derby in the cause of Hospital reform-very much owing to yourself. 


\title{
William Ogle of Derby and Florence Nightingale
}

I believe that we shall be able to furnish you with a Lady Supt. (certainly the lady we propose will not lend herself to the charge of being the 'ecclesiastical' head of a 'Sisterhood'). Mrs. Wardroper, our Matron of St. Thomas' and I had a good laugh over that paragraph of your letter, tho' I did not tell her it was yours. The lady in question will now return to Mrs. Wardroper to be further trained for a few months. And we hope to send you her and a Staff of Nurses, by Michaelmas or Christmas. But we hope we shall be allowed till Christmas.

You are doubtless aware that I have had much correspondence with $\mathrm{Mr}$. Wright.

In the present state of the question, I can scarcely interfere, in the way you kindly propose; you must fight your own Battles in which I heartily wish you God speed-and when the time comes that I am asked my opinion authoritatively you will always find me ready to give the fullest consideration in my power, or any other assistance, as far as health and business permit. I have already told Mr. Wright that any alteration in rules, necessitated by having a Lady Superintendant I would gladly look over, if desired, or any Hospital plans-(the Indian Govt. paper is still strictly private and cannot be used) in short, in any question either 'of construction or of administration' I will do my very best in giving advice if I am asked authoritatively and not controversially.

And in the mean time pray let me congratulate you on your success and augur a greater success to you.

\author{
And pray believe me, \\ My dear Sir, \\ Ever your faithful servant, \\ PLORENCE NIGHTINGALE.
}

